\title{
Front Matter: Volume 10852
}

, "Front Matter: Volume 10852," Proc. SPIE 10852, Therapeutics and Diagnostics in Urology 2019, 1085201 (17 May 2019); doi: 10.1117/12.2531182

SPIE. Event: SPIE BiOS, 2019, San Francisco, California, United States 


\section{PROGRESS IN BIOMEDICAL OPTICS AND IMAGING}

\section{Therapeutics and Diagnostics in Urology 2019}

Hyun Wook Kang

Editor

2 February 2019

San Francisco, California, United States

Sponsored by

SPIE

Cosponsored by

Boston Scientific Corporation (United States)

Published by

SPIE 
The papers in this volume were part of the technical conference cited on the cover and title page. Papers were selected and subject to review by the editors and conference program committee. Some conference presentations may not be available for publication. Additional papers and presentation recordings may be available online in the SPIE Digital Library at SPIEDigitalLibrary.org.

The papers reflect the work and thoughts of the authors and are published herein as submitted. The publisher is not responsible for the validity of the information or for any outcomes resulting from reliance thereon.

Please use the following format to cite material from these proceedings:

Author(s), "Title of Paper," in Therapeutics and Diagnostics in Urology 2019, edited by Hyun Wook Kang, Proceedings of SPIE Vol. 10852 (SPIE, Bellingham, WA, 2019) Seven-digit Article CID Number.

ISSN: 1605-7422

ISSN: 2410-9045 (electronic)

ISBN: 9781510623460

ISBN: 9781510623477 (electronic)

Published by

SPIE

P.O. Box 10, Bellingham, Washington 98227-0010 USA

Telephone +1 3606763290 (Pacific Time) · Fax +1 3606471445

SPIE.org

Copyright (C) 2019, Society of Photo-Optical Instrumentation Engineers.

Copying of material in this book for internal or personal use, or for the internal or personal use of specific clients, beyond the fair use provisions granted by the U.S. Copyright Law is authorized by SPIE subject to payment of copying fees. The Transactional Reporting Service base fee for this volume is $\$ 18.00$ per article (or portion thereof), which should be paid directly to the Copyright Clearance Center (CCC), 222 Rosewood Drive, Danvers, MA 01923. Payment may also be made electronically through CCC Online at copyright.com. Other copying for republication, resale, advertising or promotion, or any form of systematic or multiple reproduction of any material in this book is prohibited except with permission in writing from the publisher. The CCC fee code is $1605-$ $7422 / 19 / \$ 18.00$.

Printed in the United States of America by Curran Associates, Inc. under license from SPIE.

Publication of record for individual papers is online in the SPIE Digital Library.

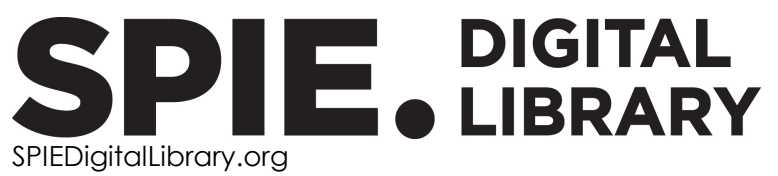

Paper Numbering: Proceedings of SPIE follow an e-First publication model. A unique citation identifier (CID) number is assigned to each article at the time of publication. Utilization of CIDs allows articles to be fully citable as soon as they are published online, and connects the same identifier to all online and print versions of the publication. SPIE uses a seven-digit CID article numbering system structured as follows:

- The first five digits correspond to the SPIE volume number.

- The last two digits indicate publication order within the volume using a Base 36 numbering system employing both numerals and letters. These two-number sets start with $00,01,02,03,04$, 05, 06, 07, 08, 09, 0A, OB ... 0Z, followed by 10-1Z, 20-2Z, etc. The CID Number appears on each page of the manuscript. 


\title{
Contents
}

\author{
$\checkmark \quad$ Authors \\ vii Conference Committee
}

\section{SESSION $1 \quad$ TREATMENT I}

1085204 Investigations on pulse-processing model for diffuser-assisted LITT on prostate cancer [10852-3]

SESSION 2 IMAGING

1085205 Optical tracking of kidney stones: preliminary studies [10852-4]

1085206 Label-free optical detection, grading, and staging of urothelial carcinoma through multimodal fibre-probe spectroscopy [10852-5]

1085207 Innovative computer vision approach to 3D bladder model reconstruction from flexible cystoscopy [10852-6]

SESSION 3 TREATMENT II

1085208 Phloroglucinol-assisted low-level laser therapy (LLLT) to prevent recurrence of urethral stricture [10852-7]

1085209 Assessment of optical detection methods for coagulation-front monitoring photothermal therapy of prostate cancer [10852-8]

\section{SESSION $4 \quad$ LITHOTRIPSY}

$108520 \mathrm{C}$ Thulium fiber laser stone dusting using an automated, vibrating optical fiber [10852-11]

$10852 \mathrm{OE}$ Comparison of single, dual, and staircase temporal pulse profiles for reducing stone retropulsion during thulium fiber laser lithotripsy in an in vitro stone phantom model [10852-13] 


\section{POSTER SESSION}

$108520 \mathrm{G}$ Comparison of 1908 and 1940-nm wavelengths for thulium fiber laser lithotripsy [10852-15]

10852 Ol Holmium:YAG vs. thulium fiber laser dusting of calcium oxalate monohydrate stones [10852-17]

$108520 \mathrm{~J} \quad$ Bactericidal activity of biofilm in flexible cystoscope under combined exposure of glutaraldehyde, 808-nm, and 405-nm laser [10852-18]

10852 OK Thulium fiber laser lithotripsy using small, medium, and large muzzle brake fiber optic tips [10852-19] 


\section{Authors}

Numbers in the index correspond to the last two digits of the seven-digit citation identifier (CID) article numbering system used in Proceedings of SPIE. The first five digits reflect the volume number. Base 36 numbering is employed for the last two digits and indicates the order of articles within the volume. Numbers start with 00, 01, 02, 03, 04, 05, 06, 07, 08, 09, OA, OB...0Z, followed by 10-12, 20-2Z, etc.

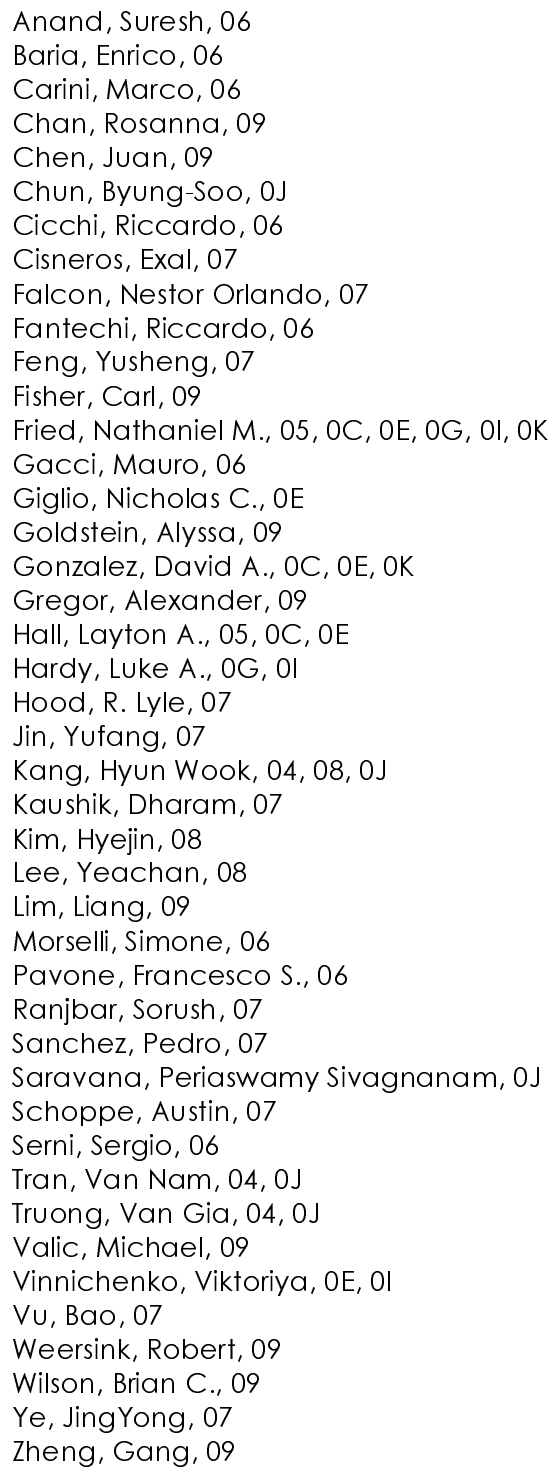


Proc. of SPIE Vol. 10852 1085201-6

Downloaded From: https://www.spiedigitallibrary.org/conference-proceedings-of-spie on 25 Apr 2023 Terms of Use: https://www.spiedigitallibrary.org/terms-of-use 


\section{Conference Committee}

Symposium Chairs

James G. Fujimoto, Massachusetts Institute of Technology (United States)

R. Rox Anderson, Wellman Center for Photomedicine, Massachusetts General Hospital (United States) and Harvard Medical School (United States)

Symposium Co-chairs

Jennifer K. Barton, The University of Arizona (United States)

Wolfgang Drexler, Medical University of Vienna (Austria)

Program Track Chairs

Brian Jet-Fei Wong, Beckman Laser Institute and Medical Clinic,

University of California, Irvine (United States)

Eva Sevick, The University of Texas Health Science Center at Houston (United States)

Conference Chair

Hyun Wook Kang, Pukyong National University (Korea, Republic of)

Conference Program Committee

Geoffrey N. Box, The Ohio State University (United States)

Kin F Chan, BioPharmX, Inc. (United States)

Nathaniel M. Fried, The University of North Carolina at Charlotte (United States)

Thomas Hasenberg, Boston Scientific Corporation (United States)

Joseph C. Liao, Stanford University (United States)

Daqing Piao, Oklahoma State University (United States)

Babak Shadgan, The University of British Columbia (Canada)

Ronald Sroka, Laser-Forschungslabor (Germany)

Joel M. Teichman, St. Paul's Hospital (Canada)

Matthias Trottmann, Universität München (Germany)

Rudolf $\mathbf{M}$. Verdaasdonk, Vrije University Medical Center (Netherlands)

Jian J. Zhang, Boston Scientific Corporation (United States) 


\section{Session Chairs}

1 Treatment I

Hyun Wook Kang, Pukyong National University (Korea, Republic of)

2 Imaging

Babak Shadgan, The University of British Columbia (Canada)

Nathaniel M. Fried, The University of North Carolina at Charlotte (United States)

3 Treatment II

Jian J. Zhang, Boston Scientific Corporation (United States)

Daqing Piao, Oklahoma State University (United States)

4 Lithotripsy

Thomas Hasenberg, Boston Scientific Corporation (United States)

Hyun Wook Kang, Pukyong National University (Korea, Republic of) 